Orientalia Christiana Cracoviensia 4 (2012), s. 25-47

DOI: http://dx.doi.org/10.15633/ochc.1029

Michał Michalski

Uniwersytet Papieski Jana Pawła II w Krakowie

\title{
Tożsamość etniczna społeczności ar-Rūsīja w świetle pochodzenia ich kultowych posągów i sposobu ich rozmieszczenia w miejscu kultu
}

W niezwykle ważnym dla określenia tożsamości ludu Rusów, a toczonym od XVIII wieku sporze między normanistami i antynormanistami ważną rolę odgrywają źródła arabskie, w których pojawia się termin ar-Rūs. Ponieważ źródła te pochodzą ze stosunkowo wczesnego okresu, do którego brakuje źródeł słowiańskich, a źródła innego pochodzenia są nieliczne, interpretacja tekstów arabskich jest szczególnie istotna. Nie bez znaczenia jest też fakt, że dostarczają one nie tylko lakonicznych wzmianek o ludzie noszącym nazwę Rusi, lecz zawierają często cenne i obszerne charakterystyki obyczajów, stosunków społecznych, religii, co pozwala wyjść poza najprostsze rozróżnienie etniczne: Normanów (Skandynawów) lub Słowian, oraz uzyskać różnorodne dane na temat czynników składających się na tożsamość wczesnośredniowiecznego ludu. Nic zatem dziwnego, że arabskie wzmianki o ar-Rūs interesują nie tylko historyków Słowian, ale też archeologów, religioznawców i etnologów.

W niniejszym artykule zamierzamy rozważyć, z kulturą jakiego ludu wiązać można obyczaje i formy kultu Rusów, znanych ze źródła zawierającego stosunkowo szczegółową charakterystykę tej społeczności w okresie, o którym niewiele jest $\mathrm{w}$ ogóle informacji ( 1 poł. $\mathrm{X}$ wieku). Tym pierwszorzędnym źródłem jest relacja z podróży, jaką odbył do kraju Bułgarów kamskich Ahmad ibn Fadlān. Spierający się uczeni próbują w relacji o społeczności ar-Rūsīja przekazanej nam przez tego autora widzieć Słowian lub Normanów. Być może w ich stanowiskach dopatrywać się można oddziaływania utartych w ich środowiskach opinii, by nie rzec, „mitów historycznych”. Nie jest jednak naszą intencją potwierdzenie tej lub innej rozpowszechnionej opinii, lecz poszukiwanie konkretnych danych, które mogą zarówno wesprzeć jedną z owych opinii, jak i obydwie - jako częściowo zgodne z prawdą. Nie przeszkadza to jednak 
temu, że pytaniem stanowiącym punkt wyjścia rozważań musi być ustalenie, jak dalece charakter kultury opisanej w relacji ibn Fadlāna był związany ze Skandynawią, a jak dalece ze Słowiańszczyzną. Postawimy przy tym pytanie, czy elementy obu kultur przeplatały się w sposób równomierny, czy jedne miały przewagę nad drugimi. Czy elementy wspólne nie wynikały z podobieństw lub dawnych związków obu kultur, czy raczej mogły być zapożyczeniami powstałymi w wyniku synkretyzmu świeżej daty?

Analizując sferę obyczajów i obrzędów religijnych społeczności ar-Rūsīja przedstawionych w dziele Ahmada ibn Fadlāna, ograniczymy się do kwestii kultowych wizerunków bóstw. Aby analiza była pełna i rzetelna, musimy zwrócić uwagę nie tylko na same boskie idole, ale także na teren, na którym te rzeźby się znajdowały, na miejsce ich ustawienia, wzajemną pozycję i ogółem na wszystko to, co wiąże się z pojęciem miejsca kultu - świątyni. Dla pełnego naświetlenia problemu ważne jest również przedstawienie opisów podobnych miejsc znajdujących się na terenie Skandynawii i Słowiańszczyzny, a poświadczonych w relacjach źródłowych innych autorów lub znanych dzięki badaniom archeologicznym. Analiza ukaże podobieństwa i różnice występujące między skandynawskimi i słowiańskimi świątyniami a kultowym miejscem opisanym przez Fadlāna.

W relacji ibn Fadlāna odnajdujemy opis okręgu świątynnego z figurami bóstw czczonymi przez ludzi ar-Rūsīja. Autor pisał, że gdy tylko przybędą oni do przystani w Bułgarze, każdy z nich wychodzi na ląd i udaje się „ku wysokiemu, umocowanemu [w ziemi] słupowi, mającemu twarz podobną do twarzy ludzkiej, wokół którego [ustawione są] małe figury, a poza tymi figurami [stoją] wysokie słupy [również] umocowane w ziemi”" Z nieco dalszej części relacji dowiadujemy się, że posągi wykonane były z drewna, a na stojących poza okręgiem palach zawieszano głowy złożonych w ofierze zwierząt ${ }^{2}$. Kultowy krąg jak się wydaje znajdował się w pobliżu siedzib ludzkich.

Układ miejsca kultowego, czyli krąg utworzony z idoli czczonych bóstw, znajduje odpowiedniki u Słowian lub pośród ludów zbliżonych do nich. Jako pozostałość podobnego układu posągów traktować można ślady po dziesięciu słupach odnalezionych we Wszczyżu nad Desną, które interpretuje się jako miejsca umocowania posągów okalających bóstwo naczelne stojące pośrodku. Miejsce to związane było z kulturą juchnowską, występującą na tym terenie na przełomie er. Dodajmy, że kultura juchnowska bywa czasami wiązana z kulturą zarubiniecką, z której wywodzi się kultura słowiańska³. Podobnym założeniem sakralnym, jak opisane u Fadlāna, był odkryty nad rzeką Hniłopiatią 7 km od

${ }^{1}$ Ahmad ibn Fadlān, Kitāb, [w:] Źródła arabskie do dziejów Słowiańszczyzny, red. T. Lewicki, t. 3, Wrocław 1985, s. 110.

${ }^{2}$ Tamże, s. 110.

${ }^{3}$ Б. А. Рыбаков, Язычество Древней Руси, Москва 1987, s. 123. 
Żytomierza kompleks będący wytworem kultury Łuka-Rajkowieckiej, zaliczanej do kręgu słowiańskiego. Centrum tego obiektu stanowił wielki pal drewniany otoczony mniejszymi słupami ${ }^{4}$. Analogiczny wygląd miały również sanktuaria w Tuszemli, a także w miejscowościach Prudki i Gorodok w regionie smoleńskim. Rekonstruując wygląd świątyni w Tuszemli, a dokładniej interesującego nas tu jej centralnego miejsca, L. P. Słupecki twierdzi, że „centralnym punktem sanktuarium była duża kolumna i kilka mniejszych słupów. Pozostałości słupów leżały wewnątrz rowu, tworząc krąg wokół tej [większej] sześciometrowej średnicy [kolumny]" ". Należy nadmienić, że kultura Tuszemla (Tuszemla-Kołoczin) jest zaliczana do wczesnych faz kultury słowiańskiej, choć niektórzy badacze kojarzą ją z Bałtami ${ }^{6}$. Powyższe przykłady można wiązać w bliższy lub dalszy sposób z kulturą słowiańską, lecz pewne jest to tylko w przypadku Hniłopiatii.

Do powyższych przykładów możemy dodać jeszcze co najmniej jeden z terenów Słowiańszczyzny Zachodniej - miejsce, gdzie według B. Dostala znajdował się podobny krąg małych figur otaczających większe bóstwo, mianowicie Břeclav-Pohansko na Morawach, sanktuarium Słowian zachodnich, w którym centralny punkt stanowić miał magiczny krąg, składający się z ośmiu symetrycznych idoli otaczających jedną większą statuę ${ }^{7}$.

Fadlān wspomina, że u ar-Rūs obok posągów bogów tworzących okrąg stały osadzone w ziemi słupy nieposiadające wizerunków bóstw, a w dalszej części swego przekazu przypisuje tym palom funkcje obrzędowe. Pod względem usytuowania opisane przez Fadlāna miejsce mogło być podobne do tego odnalezionego w Ralswiek na wyspie Rugia, gdzie obok dużej drewnianej świątyni współistniało mniejsze miejsce kultu, które znajdowało się na plaży w pobliżu portu. Miejsce to służyło być może kupcom, którzy składali tam ofiary w intencji pomyślnego handlu lub bezpiecznej żeglugi morskiej ${ }^{8}$. Nie znamy dokładnej lokalizacji miejsca ofiar opisanego w relacji ibn Fadlāna, jednak ta kultowa przestrzeń miała według niego znajdować się w pobliżu rzeki.

Dysponujemy również relacją źródłową o podobnych, jak się wydaje, obrzędowych palach przekazaną przez podróżnika hiszpańsko-arabskiego Ibrāhīma ibn Ja'kūba At-Tūrtūsziego. Dotarł on w czasie swych wypraw na Półwysep Jutlandzki, do miasta Hedeby, gdzie spisał swe uwagi dotyczące jakiegoś nieokreślonego duńskiego święta. Przy okazji dał nam świadectwo

${ }^{4}$ A. Gieysztor, Mitologia Słowian, Warszawa 2006, s. 229.

${ }^{5}$ L. P. Słupecki, Slavonic pagan sanctuaries, Warszawa 1994, s. 122.

${ }^{6}$ Б. А. Рыбаков, Язычество..., dz. cyt., s. 123.

${ }^{7}$ B. Dostal, Břeclav-Pohansko. Velkomoravsky velmožsky dvorec, Brno 1975, s. 104-110; por. Z. Klanica, Religion und Kult, ihr Reflex in archäologischen Quellen, [w:] Grossmähren und die Anfänge der tschechoslowakischen Staatlichkeit, Hrsg. J. Poulík, B. Chropovský, Praha 1986, s. 148-149.

${ }^{8}$ J. Herrmann, Ralswiek. Seehandelplatz, Hafen und Kultstätte. Arbeitsstand 1983, „Ausgrabungen und Funde. Archáologische Berichte und Informationen“ 29 (1984) z. 3, s. 133. 
o występowaniu tam podobnych słupów: „ten, który zarzyna ofiarę, ustawia przed wejściem do swojej zagrody pale i nadziewa zabite zwierzę, [...] aby ludzie wiedzieli, że składa bogu ofiarę"9. Potwierdzenie przeznaczenia takich słupów odnaleźć można także w niektórych sagach islandzkich. Uważa się, iż pale wzmiankowane przez Fadlāna nie były podobiznami bóstw, tylko słupami nidstang, zwanymi również „słupami przekleństwa”, bowiem ich instalacja wiązała się zazwyczaj z rzuceniem klątwy ${ }^{10}$. Na owych słupach, podobnych zapewne do tych z relacji At-Tūrtūsziego, umieszczano w Skandynawii głowy ofiarowanych bogom zwierząt ${ }^{11}$. Zgadzałoby się to z przeznaczeniem, jakie przypisywał im Fadlān, choć nie mamy żadnych informacji, czy łby koni i owiec, o których wspomina, wieszane były na tych palach w celu rzucenia klątwy.

Jak wynika z powyższych rozważań, ar-Rūs znani z relacji Ahmada ibn Fadlāna, tworząc krąg posągów poświęconych bogom, zachowywali się podobnie do Słowian lub pokrewnych im ludów, zaś wystawiając pale służące do składania ofiar, bliżsi byli Skandynawom. Dokonaliby oni zatem, być może, zapożyczenia zwyczajów religijnych zarówno od Słowian i innych ludów mieszkających w Europie Wschodniej, jak i Skandynawów. Należy więc ustalić, jak prezentowały się u Skandynawów i Słowian miejsca, w których znajdowały się posągi bóstw i z czego wykonane były owe idole.

Uważa się, iż kult religijny początkowo sprawowany był przez mieszkańców północy pod gołym niebem, gdzie często usadowione były idole z przedstawieniami ludzkich twarzy. Miejsca takie określano staronordyckimi terminami skurgoð lub trémadr, a występowały one zazwyczaj w miejscowościach, w których nazwie występował wyraz „kij” (stav) ${ }^{12}$. Dopiero z czasem u Skandynawów zaszły przemiany i miejsca świątynne zaczęto ogradzać oraz osłaniać dachem. Nie znaczy to jednak, że w późniejszym okresie odprawiano modły i składano ofiary tylko i wyłącznie w ogrodzonych i okrytych dachem świątyniach.

O kultowym miejscu w Danii donosi nam Thietmar z Merseburga, niestety skupił się on bardziej na sferze obrzędów i ofiar niż na samym opisie wyglądu sanktuarium, niemniej z jego relacji możemy odczytać dwie informacje, które są pomocne w rozważaniach na nasz temat. Dowiadujemy się bowiem, że miejsce to znajdowało się w stolicy Danii (caput istius regni), mieście Lederun

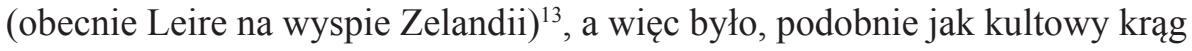

${ }^{9}$ Ibrāhīm ibn Ja'kūb At-Tūrtūszi, [w:] Arabische Berichte von Gesandten an germanische Fürstenhöfe aus dem 9. und 10. Jahrhundert, Hrsg. G. Jacob, Berlin 1927, s. 29.

${ }^{10}$ S. A. Bay, Bonde og viking; samfundsliv og tro i Nordens vikingetid, København 1954, s. 136.

${ }^{11}$ А. П. Ковалевский, Путешествие ибн Фадлана на Волгу, Москва 1939, s. 140.

${ }^{12}$ W. Duczko, Viking Rus: Studies on the Presence of Scandinavians in Eastern Europe, Leiden 2004, s. 90.

${ }^{13}$ Thietmari Merseburgensis Episcopi Chronicon, I, 17, Hrsg. R. Holtzmann, Berlin 1935, s. 22-25 (Monumenta Germaniae Historia. Scriptores Rerum Germanicarum. Nova Series, 9) [Thietmar]. 
znany nam z relacji ibn Fadlāna, umiejscowione w pobliżu siedzib ludzi, nie zaś na odludziu. Precyzyjna lokalizacja pozwala nam przyjrzeć się znaleziskom archeologicznym z tego obszaru. Badania w mieście Leire wykazały obecność pozostałości sporej budowli o rozmiarach $48 \times 11,5 \mathrm{~m} \mathrm{z}$ drugiej połowy $\mathrm{X}$ wieku ${ }^{14}$. Być może właśnie ta ,wielka hala” była miejscem centralnych uroczystości religijnych w Leire. Thietmar wspomina, że ofiary składane były na przebłaganie bogów ${ }^{15}$, co może nasuwać przypuszczenie, że znajdowały się tam jakieś przedstawienia bóstw, przy których dary były składane.

W Skandynawii istniały dwa rodzaje świątyń sensu stricto. Pierwsze z nich, wielkie podłużne kultowe hale zwane hof lub godahus. W przypadku, gdy budynki te były miejscem kultu prywatnego, nazywano je blóthus. Drugim typem świętych budowli były małe sanktuaria na planie kwadratu, zwane hörg ${ }^{16}$.

Dobrze udokumentowaną źródłowo świątynią skandynawską, należącą jak się wydaje do typu hörg, było sanktuarium w Starej Uppsali. Podobnie jak omawiane wyżej duńskie Leire, Stara Uppsala była centralnym ośrodkiem przedchrześcijańskiego kultu w średniowiecznej Szwecji ${ }^{17}$. Opis tego miejsca, jak również obrzędów odbywających się tam, przekazał nam w swym dziele Adam z Bremy. Z jego relacji wiemy, że sanktuarium było wspaniałe, a wszystko w nim zrobione było ze złota, w bezpośrednim sąsiedztwie płynęło święte źródło, a obok świątyni znajdowało się ogromne drzewo, które pozostawało zielone zarówno w zimie, jak i w lecie ${ }^{18}$. Badania archeologiczne w Starej Uppsali odsłoniły pod tamtejszym kościołem pozostałości budowli na planie kwadratu. Wygląda na to, iż był to niewielki budynek, wykonany z drewna, otoczony płotem $^{19}$. Czy są to jednak resztki opisywanej przez Adama świątyni? Tego nie możemy być pewni.

Z dalszej części przekazu Adama z Bremy, dowiadujemy się szczegółowych informacji o szerzącym się tam kulcie, a w szczególności o trzech posągach obdarzanych w Uppsali wielką czcią. „W tej świątyni, gdzie wszystko jest zrobione ze złota, ludzie czczą posągi trzech bogów, Thora, który jako najpotężniejszy posiada tron na podium, Odyna i Freja mają oni umiejscowionych zaraz po nim". W obliczu nadchodzącej zarazy obdarowywano Thora; gdy kraj stawał

${ }^{14} \mathrm{~B}$. Magnus, Dwellings and settlements: structure and characteristics, [w:] The Scandinavians from the Vendel period to the tenth century, ed. J. Jesch, Woodbridge 2002, s. 21.

${ }^{15}$ Thietmar, I, 17, s. 22-25.

${ }^{16}$ J. de Vries, Altgermanische Religionsgeschichte, t. 1, Berlin 1956, s. 372-384.

${ }^{17}$ L. P. Słupecki, Wyrocznie i wróżby pogańskich Skandynawów. Studium do dziejów idei przeznaczenia u ludów indoeuropejskich, Warszawa 1998, s. 126; S. Piekarczyk, Mitologia germańska, Warszawa 1979, s. 175.

${ }^{18}$ Magistri Adam Bremensis Gesta Hammaburgensis ecclesiae pontificum, IV, 26, schol. 138 (134), Hrsg. B. Schmeidler, Hannover 1917, s. 257-258 (Scriptores rerum Germanicarum in usum scholarum ex Monumentis Germaniae Historicis) [Adam z Bremy].

${ }^{19}$ J. Brøndsted, Die grosse Zeit der Wikinger, Neumünster 1964, s. 228-231. 
w obliczu wojny, ofiary składano Odynowi, a Frej odpowiadał za pomyślność w trakcie zawierania małżeństwa ${ }^{20}$.

Przyjęło się uważać, iż autor relacji o świątyni w Uppsali nigdy nie był w miejscu, o którym pisał, a wzmianka została napisana na podstawie opowieści naocznych świadków relacjonowanych wydarzeń. Jednakże informacje przekazywane przez Adama z Bremy mogą wzbudzać wątpliwości nie tylko z tego powodu, że nie widział on opisywanego przez siebie sanktuarium. W sytuacji, gdy kronikarz bremeński przedstawia świątynię, w której przebywały trzy figury bogów, można dopatrywać się nawiązania autora do chrześcijańskiej Trójcy św. ${ }^{21}$. Ponadto, jak uważa część uczonych, system wierzeń religijnych oparty na tych trzech bóstwach mógł być wynikiem zabiegów warstwy uprzywilejowanej, która pragnęła utrzymać swoją pozycję w społeczeństwie ${ }^{22}$. Z drugiej jednak strony należy zwrócić uwagę na koncepcję G. Dumézila, który stwierdził, iż trójpodział wśród bóstw dzielący je na odpowiadające za: 1) magię i prawo, 2) siłę i sprawność fizyczną, 3) płodność i dobrobyt, był typowy dla religii indoeuropejskich ${ }^{23}$. My uwzględniamy opis Adama z Bremy, ponieważ istnienie w świątyni trzech bóstw nawiązujących do chrześcijaństwa nie wyklucza, że posągi (choć może w innej liczbie) mogły się tam znajdować już wcześniej, zanim dotarły wpływy chrześcijańskie.

Adamowi Bremeńskiemu zawdzięczmy również inną pomocną dla nas wzmiankę, dotyczącą tym razem posągu Thora. Relacja opowiada o zniszczeniu idola bóstwa, którego dopuścił się anglosaski misjonarz Wulfrad. Próbował on odwieść Szwedów od politeizmu, w tym celu miał porąbać toporem rzeźbę Thora stojącą na placu wiecowym thingu, za co poniósł śmierć przebity włóczniami ${ }^{24}$. Wnioskując z opinii autora kroniki, kulty religijne Skandynawów koncentrowały się wokół figuralnych przedstawień bóstw ${ }^{25}$.

Kolejnym źródłem poświadczającym upodobania ludności skandynawskiej do tworzenia wizerunków bóstw i czczenia ich w formie idoli jest Olafs saga Tryggvasonar. Zawarty w niej opis objazdu posągu bóstwa w świętym wozie po określonym terenie, nawiązuje do relacji o święcie na cześć germańskiej bogini Nerthus ${ }^{26}$ kultywowanym na Półwyspie Jutlandzkim i być może jest jej

${ }^{20}$ Adam z Bremy IV, 26-27, s. 258-259.

${ }^{21}$ S. Piekarczyk, Mitologia..., dz. cyt., s. 175-176.

${ }^{22} \mathrm{O}$. Vésteinsson, The conversion of the Icelanders, [w:] Europe around the year 1000, red. P. Urbańczyk, Warsaw 2001, s. 325-342, tu również o wierzeniach pozostałej części społeczeństwa zamieszkującego Islandię.

${ }^{23}$ G. Dumézil, Les dieux des Indo-Européens, Paris 1952, s. 5-39.

${ }^{24}$ Adam z Bremy, II, 62, s. 122.

${ }^{25}$ S. Piekarczyk, Mitologia..., dz. cyt., s. 177.

${ }^{26}$ O święcie tym pisze Tacyt, por. Cornelii Taciti, De Origine et Situ Germanorum, 40, rec. Maximus Lenchantin de Gubernatis, Torino 1949, s. 28-29 (Corpus Scriptorum Latinorum Paravianum). 
skandynawskim odpowiednikiem ${ }^{27}$. Saga przekazuje opowieść o norweskim wygnańcu Gunnarze, który miał zastąpić posąg Freja podczas rytualnego objazdu po kraju Svearów (Szwedów). Po zrzuceniu idola z wozu i porąbaniu go na części wdział Gunnar na siebie jego szaty i kontynuował podróż, udając bóstwo ${ }^{28}$. Przekaz ten znajduje odzwierciedlenie w prawdziwym zwyczaju Szwedów, którzy wozili po swej ziemi idola przedstawiającego bóstwo Freja, a co po wprowadzeniu chrześcijaństwa do tego kraju zamieniło się prawdopodobnie w podobne obrzędowe objazdy królów, zwane Eriksgata, czyli „droga Eryka"29.

Również badania archeologiczne ukazują nam skłonności Skandynawów do przedstawiania swych bóstw w postaci figuralnej. Artefakty tego typu zostały odnalezione w wielu miejscach - wymieńmy choćby odkrytą w miejscowości Rällinge w Södermanland w Szwecji rzeźbę Freja wykonaną z brązu, a datowaną na późny okres wikiński ${ }^{30}$, posążek wykonany z kości morsa odnaleziony w Lund w Skanii przedstawiający przypuszczalnie Thora ${ }^{31}$, małą statuetkę z brązu przedstawiającą prawdopodobnie Thora trzymającego swój młot (miollnir) odnalezioną w północnej Islandiii ${ }^{32}$, czy znane z całej Skandynawii złote wisiory (guldgubbe) przedstawiające ściskającą się parę, związane jak się uważa, z bóstwami należącymi do rodu Wanów, a symbolizujące małżeństwa bogów ${ }^{33}$.

W Olafs saga Tryggvasonar odnajdujemy także opis sanktuarium Freja, które zniszczył król Norwegii Olaf Tryggvason. Hof zawierał posągi bóstw, a znajdował się w okolicy Trondheim. Według słów sagi posągi świątynne miały być zrzucone z piedestałów przez samego króla, inny los spotkał natomiast rzeźbę Freja. Została ona zabrana, a następnie porąbana z premedytacją przez Olafa Tryggvasona na oczach zgromadzonego na wiecu tłumu ${ }^{34}$. Nasze źródło przekazuje nam dwie ważne informacje. Pierwsza wskazuje, iż w świątyni, prócz posągu boga naczelnego, znajdowało się również kilka innych idoli, co

${ }^{27}$ L. P. Słupecki, Wyrocznie..., dz. cyt., s. 133.

${ }^{28}$ Olafs saga Tryggvasonar, 277-278, [w:] Flateyjarbok. En samling af Norske Konge-sagaer, ed. G. Vigfusson, C. R. Unger, t. 1, Christiania 1860, s. 337-339 [Olafs saga Tryggvasonar].

${ }^{29}$ L. P. Słupecki, Wyrocznie..., dz. cyt., s. 133-134, por. A. Hultgård, Kultische Umfahrt, [w:] Reallexikon der Germanischen Altertumskunde, t. 17, Berlin 2001, s. 440; por. R. Wenskus, Religion abatardie. Materialien zum Synkretismus in der vorchristlichen politischen Theologie der Franken, [w:] Iconologia Sacra: Mythos, Bildkunst und Dichtung in der Religions- und Sozialgeschichte Alteuropas: Festschrift für Karl Hauck zum 75. Geburtstag, Hrsg. K. Hauck, H. Keller, N. Staubach, Berlin 1994, s. 240.

${ }^{30} \mathrm{~S}$. H. Fuglesang, Christian reliquaries and pagan idols, [w:] Images of cult and devotion: function and reception of Christian images in medieval and post-medieval Europe, ed. S. Kaspersen, U. Haastrup, Copenhagen 2004, s. 23.

${ }^{31}$ R. Perkins, Thor the wind-raiser and the Eyrarland image, London 2001, s. 63-68.

${ }^{32}$ Tamże, s. 139, 146.

${ }^{33}$ H. R. E. Davidson, Myths and symbols in pagan Europe: early Scandinavian and Celtic religions, Manchester 1988, s. 31-32.

${ }^{34}$ Olafs saga Tryggvasonar, 322-323, s. 400-404. 
wykazuje podobieństwo do opisu Fadlāna. Druga wiadomość to fakt pocięcia rzeźby przez króla, co może wskazywać na to, że była ona wykonana z drewna, a jeśli tak było, to mamy tu do czynienia $z$ idolem sporządzonym $z$ tego samego materiału, co słupy z wizerunkami bóstw znane nam z relacji Ahmada ibn Fadlāna.

Inna saga, opowiadająca o Hrafnkellu synu Hallfreda, wspomina o wzniesieniu przez niego hofu, świątyni Freja, którego zresztą człowiek ten czcił jako jedynego boga i oddał mu połowę wszystkich swych dóbr. Przez ten fakt miał on stać się lokalnym przywódcą zwanym goði. Hrafnkels saga Freysgoða jest pomocna, gdyż jeden raz nazywa świątynię Freja goðahus (dom boga), co jest potwierdzeniem sakralności hofu wybudowanego przez Hrafnkella ${ }^{35}$. Jak twierdzi S. Piekarczyk, „budowa świątyń i nadawanie ziemi bogom mogło być wyrazem dążeń do uwolnienia danej ziemi od pretensji krewnych lub zapewnienia jakiemuś jej kawałkowi specjalnego miejsca w prawach spadkowych", w konsekwencji czego wznoszenie kultowych budowli mogło być powiązane z eksmisją z danego terenu „ludności szeregowej”"36.

Kolejny opis budowli świątynnej typu hof odnajdujemy w Eyrbyggja saga, która wspomina o norweskim notablu Thorolfie Mostrarskegg. Miał on, po sprzeczce z królem Haraldem, opuścić swój kraj i udać się do Islandii w poszukiwaniu lepszego życia. Thorolf był czcicielem Thora, więc zabrał ze sobą w podróż ziemię spod świątyni tego skandynawskiego bóstwa, a także jego wizerunek w postaci posągu wraz z filarami konstrukcji tronu, na którym ten posąg stał. Po osiągnięciu wzrokowego kontaktu z wybrzeżem Islandii ,Thorolf wyrzucił za burtę posąg bóstwa, a także filary tronu, które stały w świątyni. Równocześnie wyjaśnił, że chce się osiedlić w tym miejscu w Islandii, w którym za pozwoleniem Thora słupy przybiją do brzegu”. Rzeźba Thora wylądowała na przylądku, który nazwano Thorness, następnie Thorolf ufundował hof w zatoce, w miejscu, które nazwano Hofstaðir. „Zbudował on dużą świątynię z wejściem w jednej ze ścian. W środku, blisko drzwi stały słupy konstrukcji tronu ze świętymi gwoździami wbitymi w nie. [...] Wewnątrz głównej świątyni było miejsce (afhus) podobne w budowie do znanego w dzisiejszych czasach chóru w kościele, a pośrodku niego podwyższona platforma przypominająca ołtarz. [...] Wewnątrz chóru (afhus) w kole dookoła ołtarza, jako część budowli ustawione były statuy bogów"37.

Pozostałości budowli dużych rozmiarów z Hofstaðir w Mývatnsveit na Islandii są nam znane $\mathrm{z}$ wykopalisk archeologicznych, gmach ten nawiązuje swym kształtem do opisu zawartego w Eyrbyggja saga. Plan sporządzony na podstawie badań wykopaliskowych ukazuje wydłużony budynek składający

${ }^{35}$ Hrafnkels saga Freysgoða, 2, 6, [w:] Austfirðinga sögur. Íslenzk Fornrit, ed. J. Jóhannesson, t. 11, Reykjavik 1950, s. 99, 124.

${ }^{36}$ S. Piekarczyk, O społeczeństwie i religii w Skandynawii VIII-XI w., Warszawa 1963, s. 135.

${ }^{37}$ Eyrbyggja saga, 3-4, przeł. H. Pálsson, P. Edwards, London 1989, s. 27-29. 
się z długiego pomieszczenia, gdzie odbywały się uczty i spotkania, a także z przyległej mniejszej izby (afhus), w której stały posągi bóstw. Na zewnątrz odnaleziono również miejsce otoczone wałem. Uważa się, iż było to miejsce przeznaczone do przygotowywania potraw dla uroczystości obrzędowych ${ }^{38}$. Trzeba nadmienić, że podobne pozostałości budynków, jak te z miejscowości Hofstaðir na Islandii, odnaleziono w XIX wieku również w innych miejscach tej wyspy, a także w miejscowości Maere w Nord-Trondelag, w pobliżu Trondheim w Norwegii ${ }^{39}$, gdzie znajdował się wysokiej rangi ośrodek religijny tego regionu okresu wikińskiego. Podczas wykopalisk w Maere prowadzonych pod tamtejszym kościołem archeolodzy odnaleźli otwory w ziemi będące pozostałością po słupach podtrzymujących wcześniejszą budowlę (świątynię?), między którymi położonych było kilka złotych płytek z wytłoczonymi wizerunkami kobiety i mężczyzny. Płytki te zidentyfikowano jako (guldgubbe) ofiary wotywne powiązane z kultem płodności ${ }^{40}$. Co ciekawe, płytki (guldgubbe) odnaleziono również w innych pozostałościach budowli datowanych na okres wikiński: w Hov niedaleko Lillehammer, w Uppåkra i na wyspach Lofotach w miejscowości Borg ${ }^{41}$. Uważa się, że wodzowskie hale bardzo często wykorzystywane były do odprawiania różnego rodzaju rytuałów, a po wprowadzeniu chrześcijaństwa pomieszczenia tego typu zaadaptowali chrześcijańscy kapłani dla potrzeb celebrowania mszy ${ }^{42}$.

Zestawiając wszystkie informacje dotyczące Skandynawii, zauważamy, że występowały tam różnego rodzaju posągi używane przez tamtejszą ludność podczas praktyk religijnych. Idole te wykonane były z różnorakiego materiału, z kamienia, z kruszcu, ale bywały też drewniane, umieszczane na słupach i stojące na wolnym powietrzu, podobnie jak to miało miejsce w opisie Fadlāna. Najczęściej jednak stały one w zadaszonych świątyniach różnego typu. Trzeba również podkreślić, że zdarzało się często, iż w sanktuariach tych posąg bóstwa naczelnego przebywał w towarzystwie innych idoli pomniejszych bogów, co także nawiązuje do opisu kultowego okręgu znanego z relacji Fadlāna.

Źródła opisujące zwyczaje Słowian wspominają o dwóch typach sakralnych przestrzeni. Były nimi tzw. kapiszcza i trzebiszcza, te pierwsze, jak się uważa, nosiły znamiona specjalnych budowli, w których znajdywały się idole czczonych bóstw. Wnioskuje się to na podstawie genealogii wyrazu kapiszcze, który „etymologicznie wywodzi się od kopciu osiadającego na słupach lub

${ }^{38}$ L. P. Słupecki, Slavonic..., dz. cyt., s. 20.

${ }^{39}$ H. E. Lidén, From pagan sanctuary to Christian Church. The excavation of Maere Church in Trondelag, „Norwegian Archaeological Review” 2 (1969), s. 3-32.

${ }^{40}$ H. R. E. Davidson, Myths and symbols..., dz. cyt., s. 31-32.

${ }^{41}$ D. Skre, Kirke før sognet. Den tidligste kirkeordningen i Norge, [w:] Møtet mellom hedendom og kristendom i Norge, ed. H. E. Lindén, Oslo 1995, s. 175.

${ }^{42}$ E. Roesdahl, Hvornår blev kirkerne bygget?, [w:] Kristendommen i Danmark før 1050. Et symposium i Roskilde den 5-7 februar 2003, ed. N. Lund, Roskilde 2004, s. 205. 
dymniku”43. Zdaniem badaczy świątynie pogańskie noszące znamiona osobnych budynków specjalnie predestynowanych do pełnienia funkcji obrzędowych są jednak zjawiskiem późnym w historii wierzeń słowiańskich ${ }^{44}$. Nazwę drugiego typu sanktuariów kultu, czyli trzebiszcza, wywodzą uczeni od „trzeby”, był to najprawdopodobniej ogrodzony teren ofiarniczy pod gołym niebem. Oba te rodzaje świętych miejsc oznaczały teren wydzielony ${ }^{45}$.

Potwierdzenie posiadania przez Słowian sanktuariów i kultowych posągów przekazuje nam niemiecki kronikarz Thietmar, który opisując świątynie Redarów w Radogoszczy, wspomniał o wielbionych przez nich figurach bogów znajdujących się w jej środku: „wewnątrz stoją bogowie zrobieni ludzką ręką w pancerzach i strasznych hełmach, każdy z wyrytym u spodu imieniem. Pierwszy pośród nich nazywa się Swarożyc i szczególnej doznaje czci u wszystkich pogan"46. Jak dowiadujemy się od Thietmara, świątynia w Radogoszczy zbudowana była $z$ drewna, osadzona na fundamencie ze zwierzęcych rogów, a drewniane ściany od strony zewnętrznej przyozdobione były rzeźbami bogów i bogińn ${ }^{47}$. Posąg Swarożyca otoczony był więc przez inne idole plemienne, co wskazuje na to, iż świątynia zawierała panteon bóstw. Uważa się, że Radogoszcz była miejscem, z którego przygotowywano wyprawy wojenne. Potwierdzeniem tego są słowa Thietmara, że tam właśnie wisiały wojenne sztandary z podobiznami bóstw ${ }^{48}$. W świetle tej wzmianki można wnioskować, że Swarożyc mógł być uważany za bóstwo opiekuńcze całej osady, o zdecydowanie wojennych przymiotach ${ }^{49}$. Świątynie słowiańskie na Połabiu i Pomorzu Zachodnim z reguły umiejscowione były przy znaczniejszych plemiennych i wczesnomiejskich ośrodkach osadniczych (Brenna, Szczecin, Stargard wagryjski i in.), a część z nich, jak na przykład Radogoszcz, osiągnęła statut centrów ponadplemiennych ${ }^{50}$.

Relacja Thietmara mówi wyraźnie, że świątynia w Radogoszczy zrobiona była $\mathrm{z}$ drewna, wnioskować $\mathrm{z}$ tego można, iż także rzeźbione ludzkimi rękami idole wykonane były z tego materiału ${ }^{51}$. A jeśli tak, to należy się zastanowić nad kwestią pochodzenia rzeźbiarzy uczestniczących w procesie ich tworzenia. Pewną wskazówką są dla nas umieszczone u podnóża rzeźb imiona, wskazujące

${ }^{43}$ A. Szyjewski, Religia Stowian, Kraków 2003, s. 151.

${ }^{44}$ L. Leciejewicz, Światynie pogańskie, [w:] Stownik starożytności słowiańskich, red. G. Labuda, Z. Stieber, t. 5, Wrocław 1975, s. 570.

${ }^{45}$ A. Szyjewski, Religia..., dz. cyt., s. 151.

${ }^{46}$ Thietmar, VI, 23, s. 302-303.

47 Tamże.

${ }^{48}$ H. Łowmiański, Religia Słowian i jej upadek (w. VI-XII), Warszawa 1986, s. 172.

${ }^{49}$ A. Szyjewski, Religia ..., dz. cyt., s. 110, o dawności kultu Swarożyca, jak i o samym jego kulcie por. K. Moszyński, Kultura ludowa Słowian - kultura duchowa, t. 2, cz. 1, Warszawa 1967, s. 503-506.

${ }^{50}$ L. Leciejewicz, Świątynie pogańskie..., dz. cyt., s. 570.

${ }^{51}$ Thietmar, VI, 23, s. 302-303. 
na znajomość pisma ich twórców, niestety nie wiadomo, czy napisy były łacińskie czy runiczne, jednak, jak sądzi H. Łowmiański, „w udział chrześcijańskich artystów, których dziełem byłyby także i rzeźby bogów, trudno uwierzyć". Dlatego też pod uwagę należy wziąć kilka możliwości. Pierwsza to ta, że twórcami idoli byli artyści skandynawscy, druga - że Słowianie. Ta druga znajduje uzasadnienie w słupach perunowych z terenu Rusi. Trzecia wreszcie możliwość upatruje autorstwa we współpracy Słowian i Skandynawów ${ }^{52}$. Pewne podobieństwo do sytuacji współdziałania słowiańskich i skandynawskich rzeźbiarzy wykazują późniejsze wydarzenia, które miały miejsce, gdy po przyjęciu chrześcijaństwa, na tereny rdzennie słowiańskie dostali się różnoracy obcy artyści. Mianowicie po zetknięciu się z obfitym prądem sztuki słowiańskiej musieli oni przystosowywać obce szablony do tamtejszych potrzeb, a także wcielali się w rolę nauczycieli miejscowych rzemieślników ${ }^{53}$. Wynika z tego, iż na terenie Słowiańszczyzny istnieli już wtedy ludzie zajmujący się rzemiosłem artystycznym, z którymi kooperowali twórcy napływowi. Podobna sytuacja mogła występować w Radogoszczy w czasach, o których pisze Thietmar, gdzie w rolę artystów napływowych mogli się wcielać przybysze z północy. Ale w grę może wchodzić jeszcze inna hipoteza, dotycząca napisów znajdujących się pod idolami. Przedstawił ją L. P. Słupecki, który nie odrzucając możliwości skandynawskiego pochodzenia napisów, przychylił się jednak do wersji, iż były one wykonane alfabetem łacińskim. Według jego teorii Słowianie połabscy mieli zetknąć się z pismem łacińskim w czasie pierwszej chrystianizacji, a później po zwycięstwie reakcji pogańskiej posługiwali się tą umiejętnością między innymi do opisywania idoli bóstw ${ }^{54}$. Można wreszcie popatrzyć na słowa Thietmara sceptycznie, ponieważ wzmianka autora dotycząca napisów może wydawać się dość podejrzana ${ }^{55}$. Kryterium nieufności można rozciągnąc nie tylko na wiadomość o napisach pod rzeźbami bogów, ale także na całość informacji dotyczącej idoli, przekazaną przez autora kroniki. W opisie Thietmara zauważyć bowiem można bardzo mocne podobieństwo posągów bóstw pogańskich do kultowych figur umieszczanych w chrześcijańskich kościołach ${ }^{56}$. Dla nas jednak ważne są w tym fragmencie podobieństwa do słów ibn Fadlāna, którymi opisuje on sanktuarium Rusów. Po pierwsze Thietmar przedstawia posągi jako wykonane

${ }^{52}$ H. Łowmiański, Religia..., dz. cyt., s. 173.

${ }^{53}$ W. Hensel, Słowiańszczyzna wczesnośredniowieczna - zarys kultury materialnej, Warszawa 1965, s. 282.

${ }^{54}$ L. P. Słupecki, Einflüsse des Christentums auf die heidnische Religion des Ostseeslawen im 8.-12. Jahrhundert: Tempel - Götterbilder - Kult, [w:] Rom und Byzanz im Norden. Mission und Glaubenswechsel im Ostseeraum während des 8.-14. Jahrhunderts, Hrsg. M. Müller-Wille, t. 2, Stuttgart 1997, s. 178-179.

${ }_{55}$ S. Urbańczyk, Dawni Stowianie, wiara i kult, Wrocław 1991, s. 65.

${ }^{56}$ S. Rosik, Interpretacja chrześcijańska religii pogańskich Stowian w świetle kronik niemieckich XI-XII wieku (Thietmar, Adam z Bremy, Helmold), Wrocław 2000, s. 106. 
z drewna, druga kwestia to ustawienie w jednej świątyni boga naczelnego w otoczeniu innych, mniej znaczących bóstw.

Przy rozważaniach dotyczących Radogoszczy dysponujemy również młodszą o ok. 50 lat relacją Adama z Bremy, który używa nieco zmienionej nazwy od tej pochodzącej z przekazu Thietmara. Jak się jednak uważa, opis dotyczy tego samego miejsca. „Pomiędzy nimi [...] najpotężniejsi z wszystkich są Redarowie; gród ich to sławne miasto Retra, siedziba bałwochwalstwa. Świątynia tam wielka zbudowana została dla bożków; z tych pierwszy jest Redigast. Podobizna jego ze złota" ${ }^{57}$.

Na terenie Połabszczyzny za sprawą chrześcijaństwa wytworzyła się swoista moda na tworzenie pogańskich budynków świątynnych ${ }^{58}$. Zagadnieniem, które może nam rzucić trochę światła na kwestię, czy posągi i budowle świątynne u Słowian pojawiły się dopiero pod wpływem chrześcijaństwa, jest imię naczelnego bóstwa wymienionego przez Adama Bremeńskiego. Posiada ono inną nazwę niż w relacji Thietmara, gdyż uważa się, że Swarożyc czczony był także pod imieniem przejętym od nazwy miejsca jego kultu, Radogoszczy ${ }^{59}$. H. Łowmiański różnicę w obu relacjach thumaczy stworzeniem przez plemiona połabskie ponadplemiennego kultu Swaroga, opierającego się na wzorcach chrześcijańskich. Wierzenia te wobec rozbicia terytorialnego poszczególnych plemion, czerpiąc z chrześcijańskiego kultu świętych, wytworzyły swoisty system pomniejszych bóstw opiekuńczych zależnych od najwyższego boga Swaroga ${ }^{60}$. W opozycji do takiej interpretacji pozostaje S. Rosik, bowiem uwznioślenia bóstwa upatruje raczej w, ,przekształceniu się ogólnosłowiańskiego boga perunowego", który rozciągnąwszy swe panowanie nad mniejszymi bóstwami, sprowadził ich funkcje do roli wykonawców jego woli, a sam przejął „kontrolę nad sferą niebiańską" ${ }^{1}$. Jak dodaje uczony, relacje pisane z obszaru Rusi, jak również badania archeologiczne z terenu Słowiańszczyzny, poświadczają obyczaj ustawiania w kultowych miejscach posągu naczelnego boga w towarzystwie innych pomniejszych bóstw ${ }^{62}$.

Uważa się, że przedstawienia idolaryczne najwcześniej przyjęły się wśród Słowian Wschodnich. Wnioskuje się to z etymologii wyrazu „bałwan”, który miał być zapożyczeniem od ludów wschodnich, wschodniotureckich palvan i perskich pahlevān, co oznacza „bojownik”, „,bohater” lub „słup”63.

${ }^{57}$ Adam z Bremy, II, 21, s. 78.

${ }^{58}$ S. Urbańczyk, Dawni..., dz. cyt., s. 73.

${ }^{59}$ A. Szyjewski, Religia ..., dz. cyt., s. 109.

${ }^{60}$ H. Łowmiański, Religia..., dz. cyt., s. 170.

${ }^{61} \mathrm{~S}$. Rosik, Udziat chrześcijaństwa w powstaniu policefalnych posąów kultowych u Słowian zachodnich, Wrocław 1995, s. 92-93.

${ }^{62}$ Tamże, s. 91, badania wykopaliskowe por. L. P. Słupecki, Slavonic..., dz. cyt., s. 120-158.

${ }^{63}$ A. Gieysztor, Mitologia..., dz. cyt., s. 230. 
Spośród branych przez nas pod uwagę źródeł sporo wzmianek o posągach kultowych Słowian Wschodnich dostarcza Powieść minionych lat. Jeden z fragmentów tego dzieła informuje, iż kniaź Igor w celu złożenia przysięgi potwierdzającej zawarcie pokoju z Grekami udał się na wzgórze, gdzie znajdowało się miejsce kultowe z posągiem Peruna. Idol bóstwa stanowił zapewne najważniejszą część tego terenu. Nasze źródło informuje, że przed samą przysięgą zarówno Igor, jak i jego drużyna odłożyli broń swoją i złoto, a następnie książę wraz z Rusia pogańska przysięgali64. Niestety nie wiemy, czy było to wzgórze poza siedzibami ludzkimi, czy w ich pobliżu.

Góry i wzgórza uważane były przez Słowian za miejsca specjalne ${ }^{65}$. Wzniesienia umiejscowione w odsłoniętym terenie, zwłaszcza o łysych szczytach, na których panowały szczególne warunki i zjawiska atmosferyczne, uznawano za miejsca kontaktu z bogami ${ }^{66}$. Obecnie znamy kilka tego typu wzgórz, gdzie odbywały się praktyki religijne. Wspomnieć tu należy o największym założeniu tego typu na Łyścu (dzisiejszy Święty Krzyż), gdzie odnaleziono kamienny wał mierzący około 1,3 km długości, 2,5-3 m wysokości i 8 m szerokości u podstawy. Odnaleziono tam również kamienne posągi. Uważa się, iż pogańskie miejsce kultu istniało tam od IX do XI, a może nawet XII wieku ${ }^{67}$. Zdaniem jednak M. Derwicha kult pogański nie mógł tam być sprawowany w XII wieku, ponieważ na jego pierwszą połowę datuje się fundację tamtejszego klasztoru ${ }^{68}$. Rzeczywiście zakonnicy z pewnością nie tolerowaliby pod murami swego klasztoru odprawianego jawnie kultu pogańskiego, jednak praktyki takie mogły być sprawowane pokątnie ${ }^{69}$. Innym przykładem miejsca sakralnego podobnego typu jest góra Ślęża, gdzie całość wierzchołka otoczona była wałem okalającym ${ }^{70}$, czy Góra Grodowa w Tumlinie znajdującym się w województwie świętokrzyskim niedaleko Kielc. W tym przypadku miejsce kultu, szczyt wzgórza, opasane

\footnotetext{
${ }^{64}$ Повесть временных лет, 6453 [945], ред. В. П. Адрианова-Перетц, Санкт-Петербург 2007, s. 26 [ПВЛ].

${ }^{65}$ Z. Krzak, Święta góra i krag. Szkic prahistoryczno-mitoznawczy, „,Wiadomości Archeologiczne" 60 (1986-1990), s. 115-134.

${ }^{66} \mathrm{~A}$. Buko, The archaeology of early medieval Poland: discoveries - hypotheses-interpretations, Leiden 2008, s. 107; por. J. Maringer, Der Berg in Kunst und Kultur vor- und frühgeschichtlichen Zeit, „Zeitschrift für Religions und Geistesgeschichte“ 32 (1980) nr 3, s. 255-258.

${ }^{67}$ A. Buko, The archaeology..., dz. cyt., s. 108-109, o sceptycznych poglądach na temat funkcjonowania ośrodka pogańskiego na górze Święty Krzyż por. J. Strzelczyk, Mity, podania i wierzenia dawnych Stowian, Poznań 1998, s. 125-127.

${ }^{68}$ M. Derwich, Benedyktyński klasztor św. Krzyża na Łysej Górze w średniowieczu, Warszawa 1992, s. 177-180.

${ }^{69}$ A. Buko, The archaeology..., dz. cyt., s. 110.

${ }^{70}$ G. Domański, Ślężański zespół osadniczy i kultowy we wczesnym średniowieczu, [w:] Człowiek, sacrum, środowisko. Miejsca kultu we wczesnym średniowieczu, red. S. Moździoch, Wrocław 2000, s. 99-107 (Spotkania Bytomskie, 4).
} 
było kamiennym wałem z IX-X wieku ${ }^{71}$. Podobne miejsca sakralne Słowian znajdowały się na Rowokole, wzniesieniu na wschód od jeziora Gardno ${ }^{72}$, czy Wapiennicy w Beskidzie Śląskim³.

Trzeba jednak pamiętać, że Igor wywodził się z dynastii pochodzenia skandynawskiego, toteż jego obyczaje nie muszą wcale odzwierciedlać tradycji słowiańskiej. Według tezy tzw. normanistów Perun stojący na wzgórzu kijowskim miał być przeniesieniem na grunt słowiański kultu skandynawskiego Thora. Za prawdziwością tej teorii przemawiać miał fakt ułożenia broni pod idolem przez kniazia i jego gwardię, przed złożeniem przysięgi. Oznaczało to bowiem utwierdzenie i wzmocnienie obietnicy poprzez składanie jej na własny oręż. Jak twierdzą zwolennicy tego punktu widzenia, zwyczaj ten miał być przywieziony ze Skandynawii przez drużyny wareskie i przejęty przez ludność miejscową. $\mathrm{Z}$ taką interpretacją nie zgadza się A. Gieysztor, który twierdzi, że „nawet jeśli w części praktyki te były obce i przyniesione przez drużyny wareskie [...], napotkały na Rusi dawny autochtoniczny kult bóstwa z oczywistym imieniem słowiańskim, solidnie zakorzeniony w świadomości miejscowego społeczeństwa"74. W pewnym stopniu potwierdzają to sformułowanie S. Franklin i J. Shepard, uważając, że słowiańskie i bałtyjskie bóstwo błyskawic i suwerennej władzy było tylko adaptowane przez Rusów ${ }^{75}$. Z tezą o rzekomym normańskim pochodzeniu Peruna polemizują również inni uczeni, sugerując, iż hipoteza normanistów jest tylko częściowo prawdziwa. Traktat bowiem, którego potwierdzeniem miała być przysięga, wymienia prócz wskazanych z imienia Waregów, także ogólnie mieszkańców ziemi ruskiej, czyli głównie Słowian, a sam fakt składania przysięgi na broń znany był także ludom nie-germańskim ${ }^{76}$. Jednak nawet jeśliby odrzucić wareską genezę ,kultu Peruna na Rusi [...] i trwać na stanowisku jego rodzimości, prawdopodobny jest wpływ skandynawski na rozwój kultu"'77. Dla ścisłości wspomnieć tu należy jeszcze jedną hipotezę, upatrującą zapożyczenia obyczaju stawiania posągów przez ludność wschodniosłowiańską nie od północnych, a od ich wschodnich sąsiadów ${ }^{78}$.

Kolejny fragment Powieści minionych lat potwierdzający fakt przedstawiania przez Słowian bóstw w postaci posągów odnajdujemy w opisie życia

${ }^{71}$ J. Kuczyński, Z. W. Pyzik, Ośrodek kultu pogańskiego na Górze Grodowej w Tumlinie, pow. Kielce, [w:] Religia pogańskich Stowian, red. A. Oborny, Kielce 1968, s. 61-67.

${ }^{72}$ J. Szydłowski, Domniemany krag kultowy w Wapiennicy, pow. Bielsko, „Acta Archaeologica Carpatica" 10 (1968), s. 133-139.

${ }^{73}$ W. Filipowiak, Stowiańskie miejsca kultowe Pomorza Zachodniego w świetle badań archeologiczno-toponomastycznych, „Przegląd Zachodniopomorski” 5 (1967), s. 5-16.

${ }^{74}$ A. Gieysztor, Mitologia..., dz. cyt., s. 95.

${ }^{75}$ S. Franklin, J. Shepard, The emergence of Rus 750-1200, London 1998, s. 155.

${ }^{76}$ V. J. Mansikka, Die Religion Der Ostslaven, Helsinki 1922, s. 36.

${ }_{77}$ J. Strzelczyk, Mity..., dz. cyt., s. 147.

${ }^{78}$ S. Urbańczyk, Dawni..., dz. cyt., s. 61. 
księcia Włodzimierza w czasie, gdy był jeszcze poganinem. Źródło przekazuje: „i zaczął panować Włodzimierz w Kijowie sam, i postawił idole na wzgórzu zewnątrz dwora teremnego: Peruna drewnianego, a głowa jego srebrna, a wąs złoty, i Chorsa, Dadźboga i Strzyboga, i Simargła, i Mokosz"79. Odnajdujemy tu także informację o postawieniu podobnego posągu nad rzeką Wołchow, przez wuja Włodzimierza, ,i przyszedł Dobrynia do Nowogrodu, postawił idola nad rzeką Wołchowem" "80. Umiejętności Słowian w dziedzinie inkrustracji przedmiotów są dość dobrze poświadczone znaleziskami archeologicznymi ${ }^{81}$. Natomiast wywyższenie Peruna poprzez obdarzenie go atrybutami w postaci srebrnej głowy i złotych wąsów - przy równoczesnym braku takowych u innych posągów - było próbą swoistej reformy pogańskiego kultu, usystematyzowania hierarchii w panteonie bóstw i kodyfikacji wierzeń na Rusi ${ }^{82}$. Uwaga, jaką Włodzimierz poświęcił tym właśnie bóstwom, a przede wszystkim Perunowi, nasuwa przypuszczenie, że wiązał on z tym działaniem jakieś ambicje polityczne. Książę chciał być może wzmocnić poczucie przynależności swych poddanych poprzez wprowadzenie ogólnopaństwowej ideologii religijnej. Pragnął, by identyfikowali się oni z terenem, nad którym rozciągała się jego władza. Wywyższenie Peruna natomiast mogło być ukłonem w stronę przeważającego żywiołu słowiańskiego zamieszkującego ziemie pozostające pod jego zwierzchnością lub miało na celu zmniejszenie znaczenia drużyny wareskiej ${ }^{83}$. Być może jednak chciał on stworzyć system wierzeń, który mógłby skutecznie konkurować z nadciągającym z Bizancjum chrześcijaństwem ${ }^{84}$ lub napierającym ze wschodu islamem. My zaś w relacji tej odnajdujemy podobieństwa do opisu posągów zawartego w przekazie Ahmada ibn Fadlāna, analogię dotyczą materiału, z jakiego były wykonane idole (drewno), zauważamy również, iż stały tam figury kilku bóstw, z których jedna wywyższona była (podobnie jak u Fadlāna) do rangi boga głównego.

Badania wykopaliskowe przeprowadzone przez W. W. Chwojkę w Kijowie w 1908 roku odsłoniły (według jego interpretacji) eliptyczną kamienną platformę 4,2 m na 3,5 m, z czterema wypustkami zorientowanymi w cztery strony świata.

${ }^{79}$ ПВЛ, 6488 [980], s. 37.

${ }^{80}$ Tamże.

${ }^{81}$ S. Urbańczyk, Dawni..., dz. cyt., s. 64, o inkrustowanych znaleziskach w grodach polskich por. Kostrzewski J., Kultura prapolska, Poznań 1947, s. 282-286.

${ }^{82}$ L. P. Słupecki, Slavonic..., dz. cyt., s. 134, o zamiarze wywyższenia Peruna do rangi głównego bóstwa przez Włodzimierza por. Е. В. Аничковъ, Язычество и Древняя Русь, С.-Петербургъ 1914, s. 327.

${ }^{83}$ P. Urbańczyk, Początki państw wczesnośredniowiecznych w Europie Środkowowschodniej, [w:] Ziemie polskie $w X$ wieku i ich znaczenie w ksztaltowaniu się nowej mapy Europy, red. H. Samsonowicz, Kraków 2000, s. 68.

${ }^{84}$ Е. В. Аничковъ, Язычество..., dz. cyt., s. 327. 
Uczony twierdził, iż obiekt ten posiadał kultowy charakter ${ }^{85}$. Późniejsze badania weryfikacyjne nie potwierdziły jednak tak regularnego kształtu obiektu, jak sugerował to W. W. Chwojka.

Niedaleko Nowogrodu natomiast, na lewym brzegu rzeki Wołchow w pobliżu jeziora Ilmen, znajduje się wzgórze Perynia. Ekspedycja archeologiczna pod przewodnictwem V. V. Sedova odsłoniła tam w latach 1951-1952 kolisty plac otoczony rowem, tworzącym okrąg, pośrodku którego znajdował się ślad słupa. Ślad ten zidentyfikowano jako miejsce pozostałe po kultowym posągu. W otaczającym święte miejsce rowie odkryto natomiast pozostałości po ośmiu paleniskach ${ }^{86}$. Porównując przekaz latopisu o postawieniu posągu nad rzeką Wołchowem przez Dobrynię z badaniami archeologicznymi w Peryni, należy się zastanowić, czy mogło to być jedno i to samo miejsce, czy raczej w Nowogrodzie istniały dwa miejsca kultowe? Uważa się, że takie umiejscowienie kultowej rzeźby Dobryni należy wykluczyć, ponieważ świątynia w Peryni datowana jest na ponad wiek wcześniej od wydarzeń opisanych w Powieści minionych lat $^{87}$. Do podobnej konkluzji można dojść również z innego powodu, oprócz rozbieżności w postaci daty zauważamy bowiem fakt, iż na miejscu wykopalisk odnaleziono również drugi podobny krąg wskazujący na kultowe miejsce innego bóstwa, o którym nie wspomina kronika ${ }^{88}$. Innym ciekawym wątkiem jest brak wzmianek pisanych dotyczących wschodnich Słowian, które umiejscawiałaby posągi ich pogańskich bogów w innych niż Kijów i Nowogród ośrodkach plemiennych Rusi ${ }^{89}$. Może to wskazywać, że zwyczaj ten mógł pochodzić od Skandynawów.

Powieść minionych lat przekazuje nam również, że po chrzcie i po powrocie do Kijowa Włodzimierz nakazał niszczenie pogańskich posągów, cięto je na kawałki, wrzucano do ognia. Idol Peruna został natomiast potraktowany specjalnie, wleczono go mianowicie za koniem w asyście dwunastu ludzi uderzających posąg kijami, a następnie wrzucono rzeźbę do Dniepru. Potem Włodzimierz nakazał budować cerkwie w miejscach, gdzie wcześniej stały figury bóstw ${ }^{90}$. Jak sądzi A. Kowalik, wyróżnienie Peruna poprzez szczególny sposób zniszczenia jego figury dowodzi tego, że wcześniej właśnie Włodzimierz

${ }^{85}$ В. В. Хвойка, Древние обитатели Среднего Приднепровья и их культура в доисторические времена, Киев 1913, s. 66.

${ }^{86}$ В. В. Седов, Древнерусское языческое святилище в Перыни, [w:] Краткие сообщения Института истории материальной культуры, t. 50, Москва 1953, s. 92-103.

${ }^{87}$ S. Franklin, J. Shepard, The emergence..., dz. cyt., s. 155.

${ }^{88}$ В. В. Седов, Новые данные о языческом святилище Перуна (по раскопкам Новгородской экспедищии 1952 г.), „Краткие сообщения Института истории материальной культуры” [КСИИМК] 53 (1954), s. 105-108.

${ }^{89}$ S. Urbańczyk, Dawni..., dz. cyt., s. 62.

${ }^{90}$ ПВЛ, 6496 [988], s. 52-53. 
był głównym propagatorem, opiekunem jego kultu' ${ }^{91}$ Zdewastowanie w taki sposób tego właśnie idola miało ukazać pogańskiej ludności Rusi usunięcie ,jego kultu na płaszczyźnie ideowo-religijnej" "92. Nie znaczy to jednak, że nadszedł kres religii pogańskiej, ludność dalej kultywowała politeizm. W miejscach niedostępnych, oddalonych od wielkich centrów politycznych nadal odprawiano pogańskie obrzędy ${ }^{93}$.

Przykładami kultowych rzeźb wykonanych z kamienia są m.in. odnaleziona w Łopusznie pod Rohatyniem kamienna figura dwóch postaci wspartych o siebie plecami, obecnie przekuta na krzyż, a niegdyś służąca do pogańskich praktyk religijnych ${ }^{94}$, a także trzy znaleziska pochodzące z Iwankowic pod Kamieniem Podolskim datowane na IX i X wiek, pierwsza figura przedstawiająca bóstwo o trzech twarzach, drugi posąg wysokości $3 \mathrm{~m}$ posiadający jedną, męską twarz, a trzeci rzeźbiony na kształt ludzkiego ciała zwieńczony męską głową i posiadający miecz ${ }^{95}$.

Powieść minionych lat zawiera także słowa dosłownie ukazujące sposób wykonania kultowych posągów używanych podczas praktyk religijnych. Przekaz ten zamieszczony jest w części dotyczącej zabicia Waregów chrześcijan na ofiarę bóstwom. Jeden z nich wypowiedział słowa: ,nie są to bogowie, tylko drzewo; dziś jest, a jutro zgnije; nie jedzą bowiem, ani piją, ani mówią, tylko są zrobieni rękami z drzewa" ${ }^{\prime 96}$.

Także przedstawień kultowych idoli wykonanych z drewna, a odnalezionych na terenach Słowiańszczyzny, dostarcza nam archeologia. Przykładem znalezisk tego typu są m.in. dębowy pal mierzący $1,5 \mathrm{~m} \mathrm{z} \mathrm{X-XII} \mathrm{wieku,}$ odkryty w Behrem-Lübchin w pozostałościach obodrzyckiego grodziska ${ }^{97}$ czy wykazujący cechy antropomorficzne wizerunek bóstwa znaleziony w torfie w Alt-Friesack, datowany na VI-VII wiek, ukazujący postać o wąskim tułowiu z głową w czapce ${ }^{98}$. Figury drewniane odnajdywane były także na terenie Polski, do tej grupy należą: głowa bóstwa odkryta w Jankowie nad jeziorem Pakoskim, przedstawiająca mężczyznę o surowych rysach oraz męska głowa wyłowiona

${ }^{91}$ A. Kowalik, Kosmologia dawnych Stowian. Prolegomena do teologii politycznej dawnych Stowian, Kraków 2004, s. 148.

${ }^{92}$ L. Wojciechowski, Trojaka śmierć słowiańskich bogów, [w:] Christianitas et cultura Europae, red. H. Gapski, cz. 1, Lublin 1998, s. 595-596.

${ }^{93}$ К. М. Тальковскій, Борьба Христіанства съ Остатками Язычества въ Древней Руси, t. 1, Харьковъ 1916, s. 123.

${ }^{94}$ A. Gieysztor, Mitologia..., dz. cyt., s. 233.

${ }_{95}$ М. Ю. Брайчевский, Древнеславянское святилище в селе Иванковиьы на Днестре, КСИИМК, 52 (1953), s. 43-52.

${ }^{96}$ ПВЛ, 6491 [983], s. 38.

${ }^{97}$ E. Schuldt, Behren-Lübchin. Słowiański gród w Meklemburgii, „Z Otchłani Wieków” 37 (1971), s. 262-266.

${ }^{98}$ J. Herrmann, Altfriesack, [w:] Enziklopädie zur Frühgeschichte Europas. Arbeitmaterial, Berlin 1980, s. 24. 
z Warty w miejscowości Dąbrówka koło Radomska, posiadająca podobne rysy twarzy, jak ta z Jankowa ${ }^{99}$. Do tego wszystkiego dodać możemy również rzeźbę brodatego mężczyzny, posiadającego długie ciało zakończone krótkimi nóżkami, odnalezioną na terenach Słowiańszczyzny Wschodniej w Ładodze. Ten przedmiot identyfikowany przez wielu uczonych jako słowiański, bywa jednak czasem przedstawiany jako wytwór kultury nordyckiej ${ }^{100}$.

Zestawiając wszystkie przytoczone informacje dotyczące miejsc świętych i przedstawień bóstw czczonych przez Normanów i Słowian z wiadomościami przekazanymi nam przez Ahmada ibn Fadlāna, dostrzegamy kilka istotnych podobieństw miejsc i przedmiotów kultu tych ludów z obyczajami religijnymi ludzi ar-Rūsīja. Jeżeli chodzi o charakter miejsca kultowego, znanego z relacji Fadlāna, to pamiętamy, iż znajdowało się ono na wolnej przestrzeni.

Zauważamy, że u społeczności skandynawskiej miejsca kultowe były najczęściej sakralnymi budowlami, jednak nie znaczy to, by u Normanów zupełnie nie występowały miejsca świątynne pod gołym niebem. Dysponujemy opisem Adama z Bremy, z którego wynika, że uświęconymi miejscami na wolnej przestrzeni były place, gdzie odbywano zgromadzenia, tzw. thingi. Potwierdzenie szczególności tych miejsc odnajdujemy również w tradycji przekazanej przez skandynawskich sagamadrów.

Także u Słowian mamy do czynienia ze zwyczajem stawiania budowli świątynnych, lecz dotyczy to w głównej mierze zwyczajów Słowian Połabskich. Dysponujemy również archeologicznym potwierdzeniem kilku słowiańskich miejsc kultowych albo świątyń ludów powiązanych ze Słowianami, które znajdywały się na wolnej przestrzeni, na wzgórzach, w lasach, przy źródłach itp. Przypomnijmy wspomniane wyżej, w związku z omawianiem kręgów słupów-idoli, zabytki z Wszczyża, krąg nad rzeką Hniłopiatią koło Żytomierza, Tuszemlę czy kompleksy świątynne w miejscowościach Gorodok i Prudki - uznaliśmy je za słowiańskie lub należące do kultur bliskich Słowianom. U ar-Rūs z dzieła Fadlāna miejsce kultu nie znajdowało się jednak na terenie odosobnionym, lecz przeciwnie - w pobliżu portu, w miejscu uczęszczanym przez społeczność.

Odnajdujemy miejsca świątynne stojące na wolnej przestrzeni na Rusi Kijowskiej, znajdują się one nie w miejscu odosobnionym, lecz w mieście, w pobliżu centrum życia społecznego stolicy. Pozostałości Włodzimierzowego kompleksu kultowego w Kijowie nie wykazują co prawda identycznego układu, jak kultowy krąg Rusów opisany przez Fadlāna. Miejsca kultu, których powstanie przypisane jest Igorowi i Włodzimierzowi, władcom z dynastii skandynawskiego pochodzenia (Igor ma jeszcze imię skandynawskie!),

\footnotetext{
${ }^{99}$ W. Antoniewicz, Posagi..., dz. cyt., s. 243.

${ }^{100}$ W. Duczko, Viking Rus..., dz. cyt., s. 89.
} 
mogły być jednak tworzone pod wpływem normańskim. Opis charakteru miejsca kultowego pozostawiony u ibn Fadlāna jest więc pokrewny zarówno zwyczajom Skandynawów (przybyszom lub mieszkającym na Rusi), jak też Słowianom. Być może jednak w tym przypadku Słowianie wzorowali się na Skandynawach. Natomiast tylko u Skandynawów zauważyliśmy potwierdzenie obyczaju ustawiania słupów (zwanych tam nidstang), które nie pełniły roli idoli z podobiznami bóstw, a które przeznaczone były do zawieszania na nich części składanych ofiar, przeważnie głów.

Jak pamiętamy, krąg opisywany przez Fadlāna składał się z małych drewnianych posągów, otaczających większego - także drewnianego - idola bóstwa naczelnego. Posiadanie posągów poświadczone jest zarówno u Skandynawów, jak i Słowian, istnieją co prawda teorie, że ludy te rozwinęły obyczaj tworzenia idoli bóstw dopiero pod wpływem chrześcijaństwa, jednak nie wyklucza to całkowicie możliwości sporządzania ich przed chrystianizacją. Możliwy był wpływ Skandynawów na powstawanie kultowych rzeźb Słowian, co jednak nie znaczy, by Słowianie nie znali tego typu przedmiotów kultu wcześniej. Materiały, z których wykonywano idole przedstawiające bogów, bywały różne, ale zarówno informacje źródłowe, jak i znaleziska archeologiczne dowodzą, iż Normanowie i Słowianie wykonywali swe kultowe rzeźby także z drewna, podobnie jak ludzie ar-Rūsīja znani z interpretowanego przez nas źródła.

Ostateczny wniosek dotyczący pochodzenia posągów i okręgów sakralnych ar-Rūs oparty na analizie relacji Fadlāna i jej porównaniu z danymi dotyczącymi ludów sąsiednich musi uwzględniać bliskie związki obyczajów ar-Rūs zarówno z obrzędowością skandynawską, jak i słowiańską. Cechowali się więc oni synkretyzmem religijnym, przysposabiali obrzędy i rytuały pochodzące z innych kultur. Trudno stwierdzić, jaki typ kulturowy reprezentowali dokładnie. Mogli być Normanami, którzy przemieszczając się po terenach Rusi i dalej na wschód, prowadzili zaciągi na swe statki pośród ludności napotkanej podczas wypraw, i w ten sposób, niejako od nowych druhów przejmowali niektóre zwyczaje obce swej kulturze ${ }^{101}$.

W sporze o tożsamość etniczną ar-Rūsīja lub szerzej w dyskursie dotyczącym dwóch różnych mitologii przynależności, wizji Rusi - słowiańskiej lub normańskiej - przychodzi nam zająć pozycję pośrednią, zakładającą koegzystencję tych społeczności, która owocowała przejmowaniem obyczajów. Odpowiadając bowiem na to pytanie, nie musimy, jak się wydaje, wybierać tylko jednego z wariantów.

${ }^{101}$ D. Adamczyk, Orientalno-baltycki system handlowy a proces ksztattowania się Europy Wschodniej w IX i X wieku, [w:] Średniowiecze polskie i powszechne, red. I. Panic, J. Sperka, t. 2, Katowice 2002, s. 84, 86. 


\begin{abstract}
Abstrakt
Źródła arabskie zawierające informacje o społeczności określanej jako ar-Rūs odgrywają istotną rolę w sporze między normanistami i antynormanistami. Informacje przekazane przez arabskich podróżników oraz historyków dostarczają nie tylko lakonicznych wzmianek o ludzie noszącym taką nazwę, lecz dodatkowo zawierają cenne i obszerne charakterystyki obyczajów, stosunków społecznych oraz religii. Pozwalają zatem uzyskać różnorodne dane dotyczące czynników składających się na tożsamość tego wczesnośredniowiecznego ludu. Nie dziwi zatem, że arabskie dane dotyczące ludu ar-Rūs interesują zarówno historyków Słowian, jak również archeologów czy etnologów. W niniejszym artykule poddano rozważaniom materiał pochodzący z relacji z podróży do Bułgarów kamskich Ahmada ibn Fadlāna (1. poł. X wieku) w celu odpowiedzi na pytanie o to, z kulturą jakiego ludu można wiązać obyczaje oraz formy kultu Rusów.
\end{abstract}

\title{
Słowa kluczowe
}

Bułgarzy kamscy; Ruś; Ahmad ibn Fadlān

\section{Abstract \\ The ethnic identity of the ar-Rūsiyya community in the light of the provenience of their cult statues and the method of their arrangement in the place of worship}

The Arabic sources comprising the information about the society called ar-Rūs play an important role in the disputes between the Normanists and the Anti-normanists. The data provided by Arab travelers and historians do not only give laconic notes of the community bearing such a name, but also constitute valuable and comprehensive characteristics of their customs, social relations and religion. Therefore, they allow to obtain various information regarding the factors constituting the identity of that early Medieval society. Thus, it is not surprising that the Arabic information concerning the people called ar-Rūs engage both the historians of the Slavic people and archaeologists or ethnologists as well. In this article the material from the account of Ahmad ibn Fadlan's journey to the Kama Bulgars (the first half of the $10^{\text {th }} \mathrm{c}$.) was scrutinized to state which cultural traditions the costumes and forms of worship of the old Rus might be connected to.

\section{Keywords}

Kama Bulgars; Rus; Ahmad ibn Fadlān

\section{Bibliografia}

Adam z Bremy, Magistri Adam Bremensis Gesta Hammaburgensis ecclesiae pontificum, [w:] Scriptores rerum Germanicarum in usum scholarum ex Monumentis Germaniae Historicis, red. B. Schmeidler, Hannover 1917.

Adamczyk D., Orientalno-bałtycki system handlowy, a proces kształtowania się Europy Wschodniej w IX i X wieku, [w:] Średniowiecze polskie i powszechne, red. I. Panic, J. Sperka, t. 2, Katowice 2002. 
Ahmad ibn Fadlān, Kitāb, [w:] Źródła arabskie do dziejów Słowiańszczyzny, red. T. Lewicki, t. 3, Wrocław 1985.

Bay S. A., Bonde og viking; samfundsliv og tro i Nordens vikingetid, København 1954.

Brøndsted J., Die grosse Zeit der Wikinger, Neumünster 1964.

Buko A., The archaeology of early medieval Poland: discoveries - hypotheses - interpretations, Leiden 2008.

Cornelii Taciti, De Origine et Situ Germanorum, [w:] Corpus Scriptorum Latinorum Paravianum, t. 42, Torino 1949.

Davidson H. R. E., Myths and symbols in pagan Europe: early Scandinavian and Celtic religions, Manchester 1988.

Derwich M., Benedyktyński klasztor św. Krzyża na Łysej Górze w średniowieczu, Warszawa 1992.

Domański G., Ślężański zespół osadniczy i kultowy we wczesnym średniowieczu, [w:] Człowiek, sacrum, środowisko. Miejsca kultu we wczesnym średniowieczu. Spotkania Bytomskie $I V$, red. S. Moździoch, Wrocław 2000.

Dostal B., Břeclav-Pohansko. Velkomoravsky velmožsky dvorec, Brno 1975.

Duczko W., Viking Rus: Studies on the Presence of Scandinavians in Eastern Europe, Leiden 2004.

Dumézil G., Les dieux des Indo-Européens, Paris 1952.

Eyrbyggja saga, przeł. H. Pálsson, P. Edwards, London 1989.

Franklin S., Shepard J., The emergence of Rus 750-1200, London 1998.

Fuglesang S. H., Christian Reliquaries and Pagan Idols, [w:] Images of cult and devotion: Function and Reception of Christian Images in Medieval and Post-Medieval Europe, red. S. Kaspersen, U. Haastrup, Copenhagen 2004.

Gieysztor A., Mitologia Stowian, Warszawa 2006.

Hensel W., Stowiańszczyzna wczesnośredniowieczna - zarys kultury materialnej, Warszawa 1965.

Herrmann J., Altfriesack, [w:] Enziklopädie zur Frühgeschichte Europas. Arbeitmaterial, Berlin 1980.

Herrmann J., Ralswiek. Seehandelplatz, Hafen und Kultstätte. Arbeitsstand 1983, [w:] Ausgrabungen und Funde. Archáologische Berichte und Informationen, t. 29, z. 3, Berlin 1984.

Hrafnkels saga Freysgoða, [w:] Austfirðinga sögur. Íslenzk Fornrit, red. J. Jóhannesson, t. 11, Reykjavik 1950.

Hultgård A., Kultische Umfahrt, [w:] Reallexikon der Germanischen Altertumskunde, t. 17, Berlin 2001.

Ibrāhīm ibn Ja'kūb At-Tūrtūszi, [w:] Arabische Berichte von Gesandten an germanische Fürstenhöfe aus dem 9. und 10. Jahrhundert, red. G. Jacob, Berlin 1927.

Klanica Z., Religion und Kult, ihr Reflex in archäologischen Quellen, [w:] Grossmähren und die Anfänge der tschechoslowakischen Staatlichkeit, red. J. Poulík, B. Chropovský, Praha 1986.

Kowalik A., Kosmologia dawnych Stowian. Prolegomena do teologii politycznej dawnych Stowian, Kraków 2004.

Krzak Z., Święta góra i krąg. Szkic prahistoryczno-mitoznawczy, „Wiadomości Archeologiczne" 60 (1986-1990).

Kuczyński J., Pyzik Z. W., Ośrodek kultu pogańskiego na Górze Grodowej w Tumlinie, pow. Kielce, [w:] Religia pogańskich Stowian, red. A. Oborny, Kielce 1968.

Leciejewicz L., Światynie pogańskie, [w:] Słownik Starożytności Słowiańskich, red. G. Labuda, Z. Stieber, t. 5, Wrocław 1975.

Lidén H. E., From pagan sanctuary to Christian Church. The excavation of Maere Church in Trondelag, [w:] Norwegian Archaeological Review, t. 2, Oslo 1969. 
Łowmiański H., Religia Stowian i jej upadek (w. VI-XII), Warszawa 1986.

Magnus B., Dwellings and settlements: structure and characteristics, [w:] The Scandinavians from the Vendel period to the tenth century, red. J. Jesch, Woodbridge 2002.

Maringer J., Der Berg in Kunst und Kultur vor- und frühgeschichtlichen Zeit, [w:] Zeitschrift für Religions und Geistesgeschichte, t. 32, nr 3, Koln 1980.

Moszyński K., Kultura ludowa Stowian - kultura duchowa, t. 2, cz. 1, Warszawa 1967.

Perkins R., Thor the Wind-Raiser and the Eyrarland Image, London 2001.

Piekarczyk S., Mitologia germańska, Warszawa 1979.

Piekarczyk S., O Społeczeństwie i religii w Skandynawii VIII-XI w., Warszawa 1963.

Roesdahl E., Hvornår blev kirkerne bygget? [w:] Kristendommen i Danmark før 1050. Et symposium i Roskilde den 5-7 februar 2003, red. N. Lund, Roskilde 2004.

Rosik S., Interpretacja chrześcijańska religii pogańskich Stowian w świetle kronik niemieckich XI-XII wieku (Thietmar, Adam z Bremy, Helmold), Wrocław 2000.

Rosik S., Udziat chrześcijaństwa w powstaniu policefalnych posagów kultowych u Stowian zachodnich, Wrocław 1995.

Schuldt E., Behren-Lübchin. Słowiański gród w Meklemburgii, „Z otchłani wieków” 37 (1971).

Skre D., Kirke før sognet. Den tidligste kirkeordningen i Norge, [w:] Møtet mellom hedendom og kristendom i Norge, red. H. E. Lindén, Oslo 1995.

Słupecki L. P., Einflüsse des Christentums auf die heidnische Religion des Ostseeslawen im 8.-12. Jahrhundert: Tempel - Götterbilder - Kult, [w:] Rom und Byzanz im Norden. Mission und Glaubenswechsel im Ostseeraum während des 8.-14. Jahrhunderts, red. M. Müller-Wille, t. 2, Stuttgart 1997.

Słupecki L. P., Slavonic pagan sanctuaries, Warszawa 1994.

Słupecki L. P., Wyrocznie i wróżby pogańskich Skandynawów; studium do dziejów idei przeznaczenia u ludów indoeuropejskich, Warszawa 1998.

Strzelczyk J., Mity, podania i wierzenia dawnych Stowian, Poznań 1998.

Szydłowski J., Domniemany krag kultowy w Wapiennicy, pow. Bielsko, „Acta Archaeologica Carpatica" 10 (1968).

Szyjewski A., Religia Słowian, Kraków 2003.

Thietmar, Thietmari Merseburgensis Episcopi Chronicon, [w:] Monumenta Germaniae Historia. Scriptores Rerum Germanicarum - Nova Series, red. R. Holtzmann, t. 9, Berlin 1935.

Urbańczyk P., Poczatki państw wczesnośredniowiecznych w Europie Środkowowschodniej, [w:] Ziemie Polskie w X wieku i ich znaczenie w ksztaltowaniu się nowej mapy Europy, red. H. Samsonowicz, Kraków 2000.

Urbańczyk S., Dawni Stowianie wiara i kult, Wrocław 1991.

Vésteinsson O., The Conversion of the Icelanders, [w:] Europe Around the Year 1000, red. P. Urbańczyk, Warsaw 2001.

Vries de, J. Altgermanische Religionsgeschichte, t. 1, Berlin 1956.

Wenskus R., Religion abatardie. Materialien zum Synkretismus in der vorchristlichen politischen Theologie der Franken, [w:] Iconologia Sacra: Mythos, Bildkunst und Dichtung in der Religions- und Sozialgeschichte Alteuropas: Festschrift für Karl Hauck zum 75. Geburtstag, red. K. Hauck, H. Keller, N. Staubach, Berlin 1994.

Wojciechowski L., Trojaka śmierć słowiańskich bogów, [w:] Christianitas et Cultura Europae, red. H. Gapski, cz. 1, Lublin 1998.

Аничковъ Е. В., Язычество и Древняя Русь, С.-Петербургъ 1914.

Брайчевский М. Ю., Древнеславянское святилище в селе Иванковиь на Днестре, [w:] Краткие сообщения Института истории материальной культуры, t. 52, Москва 1953.

Ковалевский А. П., Путешествие ибн Фадлана на Волгу, Москва 1939.

Повесть Временных Лет, red. В. П. Адрианова-Перетц, Санкт-Петербург 2007. 
Рыбаков Б. А., Язычество Древней Руси, Москва 1987.

Седов В. В., Древнерусское языческое святилище в Перыни, [w:] Краткие сообщения Института истории материальной культуры, t. 50, Москва 1953.

Тальковскій К. М., Борьба Христіанства съ Остатками Язычества въ Древней Руси, t. 1, Харьковъ 1916.

Хвойка В. В., Древние обитатели Среднего Приднепровья и их культура в доисторические времена, Киев 1913. 
